\title{
Living through the legacy: the Apartheid Archive Project and the possibilities for psychosocial transformation
}

\author{
Norman Duncan', Garth Stevens ${ }^{2}$ and Hugo Canham ${ }^{3}$ \\ ${ }^{1}$ Faculty of Humanities, University of Pretoria, South Africa \\ ${ }^{2}$ Department of Psychology, School of Human and Community Development, University of the Witwatersrand, South \\ Africa \\ ${ }^{3}$ Transformation and Employment Equity Office, University of the Witwatersrand, South Africa \\ Corresponding author: \\ Norman Duncan, University of Pretoria, Private Bag X20, Hatfield, South Africa. Email: Norman.Duncan@up.ac.za
}

\begin{abstract}
The Apartheid Archive Project is an ongoing, collaborative research project that focuses on the collection of personal stories and narrative accounts from ordinary South Africans about their experiences of racism during apartheid. The primary aim of this initiative is to provide a forum for differing sectors of South African society to share and reflect on their past experiences, in the hope that these will offer us an array of alternative entry points into the past, in addition to the accounts of historians and other scholars. Crucially, the project aspires not merely to record these accounts-in itself an important act of remembering different histories - but also to engage thoughtfully and theoretically with them. In these ways, the Apartheid Archive Project encourages both a commitment to personal and collective remembering, and a joint intellectual and political commitment to interrogating stories and narratives rather than simply accepting them at face value. An intellectual and political cornerstone of the project is to contribute to a form of critical psychosocial mnemonics. Critical psychosocial mnemonics is interested in engaging with those mechanisms and processes that facilitate individual and collective remembering; how these memories intersect with lived experiences and various histories; what they can temporally reveal about the past, the present and an imagined future; how they reflect and/or construct the psychological and social subject, intersubjectivity and intergroup relations; and how they may allow us to make critical, analytic commentaries about the social world and its psychological inscription.
\end{abstract}

\section{Keywords}

Apartheid Archive Project, memory, narratives, psychosocial, race, racism, stories 
Men [and women] make their own history, but they do not make it just as they please; they do not make it under circumstances chosen by them, but under circumstances directly found, given and transmitted from the past. The tradition of all the dead generations weighs like a nightmare on the brain of the living.

(Marx, 1869/1977, The Eighteenth Brumaire of Louis Bonaparte)

\section{A legacy to die for?}

It is merely two decades since the installation of the first post-apartheid government in South Africa that heralded the transition to a fully enfranchised and democratic political dispensation, and this historical juncture represents an opportune instance to robustly reflect on the challenges that endure in transforming South African society in relation to its racialised past. Critically, there are many South Africans who today, when referring to pre-1994 South Africa, appear to suggest that the excesses of the apartheid order never really took place, that a significant proportion of the South African population was not complicit in these excesses, or indeed, that apartheid did not have a profoundly devastating impact on the lives of millions of South Africans through the Group Areas Act of 1950, the Population Registration Act of 1950, the Reservation of Separate Amenities Act of 1953, and the Bantu Homelands Citizens Act of 1970, among others (South African History Online, 2014). ${ }^{1}$

The Apartheid Archive Project, which was officially launched in 2009, departs from the assumption that it is partly because of this consistent elision or denial of the racism of the past, that we are currently witnessing a legacy that is characterised by the re-emergence of some of the vilest expressions of racism that were so frequently associated with the old order. ${ }^{2}$ For example, since 2004, South Africa has experienced a series of some of the most harrowing manifestations of racism many of which must certainly revivify memories of the dark days of the apartheid era. Disconcerting incidents such as the following, which have been reported with increasing regularity in the media in recent years, cannot but serve as ineluctable reminders and post facto evidence of the perverse legacy of the apartheid order:

14 January 2008: Johan Nel (18) [a white youth] went on a shooting spree at Skierlik informal settlement, killing four [black] people, including a three-month-old baby, in an apparent race-related attack . . . North West Safety and Security MEC Phenye Vilakazi said the murders were racially motivated. He said there was no other explanation. (Thakali, 2008, p. 15)

15 February 2008: In Pretoria, reported racial tension among pupils led to the stabbing of two Hoërskool Akasia teenagers in a fight outside the school grounds. Three coloured boys were arrested and appeared in court for the incident, while two white boys were hospitalised. Pupils at the school protested to the school's principal about a failure to address complaints of discrimination. Some students claimed there had long been white-on-black racism at their school. (Thakali, 2008, p. 15)

27 February 2008: A video made by four white University of the Free State students, in which five black workers were taken through a series of degrading mock initiation activities . . increased racial tensions. The students made the video in protest against the forced [racial] integration of Reitz hostel. (Thakali, 2008, p. 15)

May 2008: South Africa was rocked by a series of brutal xenophobic attacks against foreigners. These attacks led to the death of 62 people and the displacement of approximately 30000 foreign nationals, all of them people of colour. (Reuters, 2008, n.p.)

20 February 2014: In an incident that mirrors a 2010 attack, two white students on Monday allegedly drove over a black student as he was walking on a pavement and then later beat him ... The attackers allegedly 
tried driving over three female black students before driving over Dumane Gwebu who was admitted to hospital after the incident ... the women claimed that the assailants called them 'kaffirs' and then drove off. (City Press, 2014, n.p.)

26 February 2014: Students at one of the campuses of the North West University performed the Sieg Heil salute during a supposed orientation ceremony ... The images of students raising their right hands at the end of a song sparked the ire of the department of higher education. It said the pictures showed a group of students 'dressed in uniforms, marching in unison like troopers and, most disturbingly doing the ... Nazistyle fascist salute'. (Mail \& Guardian, 2014, n.p.)

Various commentators such as Oakley-Smith (in Faul, 2008) have observed that rather than progressively becoming less pronounced (as would have been expected, given the increasing maturation of post-1994 democratic structures and processes in South Africa), racism at times appears to becoming more salient and disconcertingly recalcitrant in contemporary South Africa.

Of course, there are the much more quotidian or everyday racist processes that obstinately remind us of the apartheid days, but which do not grab the imagination of the media in quite the same manner as the more dramatically 'sensational' events previously described. Elsewhere, Essed (1991) has called these processes 'everyday racism'. These include the ongoing battles of hundreds of thousands of impoverished Black people still trying to access a life better than the one that they had been relegated to by the apartheid order. For example, 17 years into the democratic era in South Africa, the 2011 Labour Force Survey showed that $36.7 \%$ of Black Africans in South Africa were employed compared to $64.5 \%$ of White people. Based on the measure of those seeking jobs, unemployment rates were 28.9\% and 5.6\%, respectively (Statistics South Africa, 2011). Furthermore, government statistics revealed that only $10 \%$ of Black households fall within the top income bracket in South Africa, compared to $65 \%$ of White households (Faul, 2008).

South Africa's political transition has resulted in a reintegration into the regional and global economies. Simultaneously, levels of (largely racialised) disparity and inequality have been growing, fuelled in part by the burgeoning of oligarchies and multi-national corpocracies that have reinvested within the economy as well as by a culture of individual entrepreneurship, a frenzied economic feeding for self-enrichment, cut-throat corporate competition, and a drive for individual economic and social mobility (Bond, 2000; Desai, 2002; Terre Blanche, 2006). Gqubule (2006) also noted that economic transformation has certainly not been in step with political change, and this is evidenced today in the rolling mining strikes along the Platinum Belt, as well as the highly racialised service delivery protests seen in so many Black, working-class communities. Within this context, any meaningful attempts at addressing the sedimented effects of apartheid racism are increasingly being marginalised.

Villa-Vicencio (2008) provides a rather poignant illustration of how the neglect of the racism of the apartheid order is currently perpetuating the consequences of the said order:

A recent visit to Vryburg ... presented me with a picture of excessive opulence cheek by jowl with poverty and exclusion - divided largely along racial lines. Young white males swagger in the streets with holstered guns on display. Black learners are relegated to schools that barely function, in order to allow white learners to pursue the privileges their parents demand. The main high school . . a an 'Afrikaans school' ... is essentially white, and an 'an English school' ... is black. (p. 24)

Given South Africa's apparent self-imposed, and in certain respects, carefully managed, amnesia about the apartheid era (cf. Villa-Vicencio, 2004), as well as its blindness to the ongoing impact of the institutionalised apartheid racism of the past on inter-group and inter-personal relationships (as evidenced by the reports and statistics previously presented), we believe that it is important for South African society to review its past, so as to acknowledge and address it. It is acknowledged 
that the Truth and Reconciliation Commission (TRC) has already made a critical contribution to this process (Cassan, Cayla, \& Salazar, 2004; Villa-Vicencio, 2004). However, given the TRC's tendency to focus on the more 'dramatic' or salient narratives of apartheid atrocities and the fact that it thereby effectively (albeit unintentionally) foreclosed the possibility of an exploration of the more quotidian, but pervasive and no less significant, manifestations of apartheid abuse, means that much of the details of apartheid racism have not been publicly acknowledged or assessed. It is largely for this reason that the Apartheid Archive Project has, since its inception, endeavoured to foreground stories and narratives of the everyday experiences of 'ordinary' South Africans during the apartheid era, rather than simply focusing on the 'grand' narratives of the past or the privileged narratives of academic, political, and social elites. In effect, the project attempts to fill the gaps interspersed between the 'grand' narratives recorded by the TRC and the carefully orchestrated amnesia about the past.

Given that 20 years have elapsed since the official demise of apartheid, the current period presents a singular historical opportunity to engage in an excavation and re-appraisal of our past. However, the Apartheid Archive Project is not merely oriented towards this past, but also to the present and the future. Not only has there been an emergence of a new generation that has been relatively 'untainted' by the institutional forms of racism that epitomised apartheid, but this generation also in some way represents a rupture in the continuity of the historical archive. Rather than engaging our past in a manner that attempts to engender a definitive closure to this racialised history, we are also deeply interested in understanding how young South Africans engage with this legacy and live through it in more generative ways. The question that then arises is how do young South Africans who have been part of the 'born free' generation relate to their freedom and subjectivity in a country that has been systematically defined by its racialised past and history? How do we 'do' or perform the idea of freedom in a context that is ostensibly free from apartheid, but yet integrally connected to this legacy of a recent racialised past? This project therefore hopes to contribute to the development of a historical archive which the post-1994 generation and future generations may draw upon, and allows for a vast network of silenced life stories and narratives to be recorded before they are lost to history.

\section{Possibilities for psychosocial transformation}

In essence, the Apartheid Archive Project aims to examine the nature of the experiences of racism of (particularly 'ordinary') South Africans under the old apartheid order and their continuing effects on individual and group functioning in contemporary South Africa. Thus, the project gathers stories and narratives of both Black and White South Africans, of representatives from elites and marginalised social categories, of racist perpetration and victimisation, and of complicity, trauma, and resilience. Importantly for us, the role of psychology as a disciplinary lens has the critical potential to offer certain insights into how a transformative psychosocial praxis may be realised in relation to race, racism, and associated social asymmetries.

In particular, this disciplinary lens allows us to revisit and refigure the archive as a site of liberation and democratisation, as individual stories and narratives have the potential to challenge the 'grand' narratives of official histories that tend to occlude the voices and experiences of ordinary South Africans whose identities and subjectivities continue to be shaped by their memories and experiences of the apartheid order (Stevens, Duncan, \& Sonn, 2013). Here, stories and narratives have a liminal quality, allowing for a reflection of the past, but through the narrational context of the present. The Apartheid Archive Project therefore encourages the study of a critical psychosocial mnemonics - a terrain in which memory is invoked and utilised to craft stories of the past, but in which the story itself is constantly transformed as a function of the narrational context 
of the present; where stories can tell us more about our past, but simultaneously about our present and a future that is yet to unfold; and also where memories and stories can tell us as much about personal experiences as about the social world in which they are situated (Stevens, Duncan, \& Hook, 2013). Given the over-determined nature of racism and racialisation processes, such a framing also gives us the opportunity to examine the material, social, cultural, and libidinal or affective components that sustain, reproduce, and contest such racialisation processes (Stevens, Duncan, \& Hook, 2013). From a methodological perspective, much of the work of the Apartheid Archive Project could be characterised as falling within the domain of a decolonising praxis, focusing on the recalcitrant socio-cultural and psychosocial resonances of race within the postcolonial context, and foregrounding the subaltern voice as a means of avoiding how silences can often relegate the experiences of the marginalised to the shadows of consent in matrices of social inequality (Sonn, Stevens, \& Duncan, 2013). Furthermore, the very nature of the project occupies the symbolic and applied psychoanalytic function of a potential space, a transitional space, and a containing space in which unprocessed experiences of the past that may be imbued with traumatic libidinal content can in fact be processed both personally and socially, allowing for the forging of alternate subjectivities and collective memories (Long, 2013). This function in turn has the potential for creating public dialogue, citizen participation, and intercommunal spaces in which a 'knowing' of the self and the other can be realised in processes of social transformation (Stevens, Duncan, \& Sonn, 2013).

\section{Why stories matter}

We have elected to conduct most of the research emanating from and in part constituting the Apartheid Archive Project within a qualitative framework, largely in recognition of the value of the qualitative tradition in giving voice to the marginalised as well as to capture the nuances, complexities, and contradictions that form part of the human experience. Furthermore, this framework is given preference because it places social subjects' experiences at the centre of processes of knowledge production and generation within the research endeavour. The project attempts to provide a space that affords ordinary South Africans the opportunity to place their stories in unmediated form at the centre of public record, scrutiny, commentary, and analysis.

Specifically, the analysis of stories and narratives is a central feature of much of the research conducted within the project. To paraphrase Sonn et al. (2013), stories do matter, because of their pivotal functions in the construction of identities, subjectivities, and collective narratives. Lieblich, Tuval-Mashiach, and Zilber (1998) note that narratives can either 'be the object of research or a means for the study of another question' (p. 2). Within the context of this project, narratives are largely analysed in relation to both their form and their content, and thus serve as both objects and vehicles of analytical study.

Hatch and Cunliffe (2006) state that it is our individual stories that give meaning to and construct our lives. They add that because we live our lives within social and historical contexts, they are 'intertwined with organisational, social, and historical narratives' (Hatch \& Cunliffe, 2006, p. 198). Narratives are therefore never pure reflections of deeds, behaviours, and events. They are always sites within which the personal investments of speakers, listeners, and the invisible interlocutors who may apprehend such stories, and the influence of the social context on our interpretations of the world converge to give rise to a constructed version of the event (Sands, 2004). Along similar lines, Chase (1995) notes that 'we serve our theoretical interpretation in general social processes when we take seriously the idea that people make sense of life experiences by narrating them' (p. 22). Foucault (1975) argues that narratives therefore allow for speakers and their actions to be elevated from 'the familiar to the remarkable, the everyday to the historical' (p. 204). In this 
manner, this project aims to insert the experiences of 'ordinary' South Africans into the written, 'authorised' history of South Africa.

Hyden and Overlien (2004) also posit that the narrative is the basic means through which humans give meaning to experience. Similarly, Josselson and Lieblich (1995) state that, 'the ultimate aim of the narrative investigation is the interpretation of experience' and that narrative makes possible contact between the researcher and the participants as people engaged in the process of interpreting themselves (p. ix). Researchers, therefore, have access to the context of the interview (or written text) as well as the words spoken to represent a lived life. The role of the researcher is in the interest of reaching a new interpretation or new meaning of the raw data of the experience (Addison, 1992; Josselson \& Lieblich, 1995).

Ross (2000) states that 'among the most characteristic approaches in the Critical Race Theory genre are storytelling, counter-storytelling, and analysis of narrative' (p. 41). In addition to the fact that Black history (and its ability to recall its racist colonial beginnings outside of the colonisers' meticulously white-washed records) has been passed on through the art of storytelling, narrative accounts have also been found to be powerful in that they allow the protagonists an agency to tell their story in their own words (Sonn et al., 2013). In the context of reflecting on racism, the value of this agency in re-humanising marginalised groups cannot be overstated.

Narratives and storytelling have elsewhere (Lieblich et al., 1998) been likened to therapy, and their effects as cathartic. While the Apartheid Archive Project does not seek to make claims of the therapeutic effects that storytelling has on the participants (although there is certainly the hope that this could be an outcome of the project), it does claim to provide a space for the emergence of multiple voices, and the inscription of these voices into the recorded history of South Africa. This project not only solicits stories and narratives from the direct victims of apartheid racism, but also actively encourages racially privileged groups to recount personal narratives that allow for reflections on the effects of apartheid racism on themselves as complicitous perpetrators and indirect victims. An acknowledgement of one's role in perpetuating the racist ideology of the state, even indirectly, is possible and desirable for social transformation.

While apartheid has frequently been seen to be personified by the likes of Hendrik Verwoerd, John Vorster, Adriaan Vlok, Eugene De Kock, and Wouter Basson, it was ordinary enfranchised citizens that repeatedly renewed their mandate implicitly or explicitly. Moreover, the daily 'work' of apartheid was carried out in 'routine', 'everyday' racist interactions with the subjugated. Therefore, such stories and narratives represent a critical component of the historical archive through which South Africans may come to terms with their past, as a means of coming to terms with their present.

\section{Practicalities of praxis}

In the main, the project's primary objective is to collect stories and narratives from a range of adult research participants from South Africa and the South African diaspora. Participants are requested to recount their earliest or most significant experience, or series of related experiences of racism in narrative form, which would include the following essential details: (a) the approximate year(s) in which they were exposed to or involved in the experience or series of experiences reflected on; (b) the place, key protagonists, and antagonists; and (c) the impact, if any, this experience or series of experiences may have had on their relationship to themselves and others. Logistically, the researchers request volunteers and key informants to share whatever personal experiences or stories they can think of, which for them, epitomised life and the racism of the apartheid order. These descriptive narratives are gathered by means of the project's Internet portal (http://www.apartheidarchive. org), e-mails to selected individuals, and audio-recorded face-to-face interviews. 
Our interest lies in participants' stories and narratives of their experiences of racism from the pre-democratic period of South Africa's history. In this sense, the focus of the project is located in the 'pre-history' that the apartheid era appears to have become. We problematise the notion of 'prehistory' and point to how the apartheid past lives on in the present. This is critical, given that much of what is considered exciting, vibrant, new, and therefore worthy of research in the Social Sciences and Humanities in South Africa today, is deemed to have occurred after 1994. As previously indicated, there is an overwhelming sense that mainstream writing increasingly avoids a robust engagement with this 'pre-history'. Accounts that do exist frequently encourage ignorance and elisions and the consequent silence has prompted a hegemonic discourse that minimises the historical and continued effects of apartheid racism. This negation of an appalling system of race-based oppression has served to systematically deprive an entire generation of people of the opportunity and space to recount their stories and to understand their present life circumstances, and very importantly, to contribute to the construction of South Africa's recent history.

Contributors to the archive are invited to 'gift' their stories to the project by means of a formal invitation that is posted on the project's Internet portal, attached to e-mails directed to selected recipients, or completed by contributors prior to our face-to-face interviews with them. The project currently comprises a core research team of co-researchers who are based in South Africa, the United Kingdom, the United States, and Australia. Given that we believe that this project should embody a collective attempt to address our shared past, it encourages interdisciplinary collaborations (involving, among others, sociologists, historians, anthropologists and psychologists) within the academy, both in South Africa and internationally.

Of course, as Macleod (2004) notes, the 'objective outsider' status assumed in traditional research is untenable within this project and we have not attempted to minimise the 'investigator effect'. Instead, reflexivity (that is, an awareness on the part of researchers of the constraints that they potentially impose on, and the power they have in relation to participants based on their own positionalities) is called for. Thus, as Macleod (2004) recommends, the inherent power-relations in knowledge production should be uppermost in the minds of the researchers so as to avoid as far as possible the unwitting usurping of the voices of others, which bell hooks (1990) refers to in her critique of academic pursuits of this nature.

\section{Complexities of the raced subject}

To date, the project has hosted four national conferences, and has generated more than 50 peerreviewed publications and more than 100 public presentations on the complex nature of raced subjectivities in apartheid and post-apartheid South Africa. Rather than attempting to understand these subjectivities in the context of the lofty ideals of reconciliation, which itself has become a free-floating signifier to embody a diverse range of personal and political interests, Nuttall's (2009) concept of entanglement is perhaps more useful to locate this work. Straker (2013) highlights how the histories of Blacks and Whites, together with their associated subject positions, are intertwined and entangled in ways that both reproduce and contest the oppressor-oppressed binary in subtle and complicated ways in both apartheid and post-apartheid South Africa. Consequently, our work has focused on these complexities in subject positions and the possibilities that they may yield for dialogue, understanding and psychosocial transformation in contemporary South Africa. More specifically, various researchers have highlighted the gendered nature of racialisation processes (Shefer, 2013; Sullivan \& Stevens, 2013), the sexualisation of race (Ratele \& Shefer, 2013), memory and witnessing as a vehicle for psychosocial transformation (Laubscher, 2013), the precariousness of blackness and whiteness (Straker, 2013), racialised subjectivities and diasporic communities (Sonn, 2013), the affective or libidinal dimensions of racialisation processes (Hook, 2013; Long, 
2013), methodological tensions in the use of stories and narratives (Eagle \& Bowman, 2013), the intersections of race and space, and the emergence of nostalgic formulations of the past in differential styles of remembering among the stories and narratives (Duncan, Stevens, \& Sonn, 2012), to mention but a few.

\section{Not lost in translation}

In the main, this project envisages a reconstruction of aspects of the racism of the apartheid order (as narrated by a range of social actors), as a means not merely of understanding the functioning and mutation of this phenomenon over time, but also as an attempt to understand and address the problems of racism still confronting South Africa. However, a central feature of the project is a commitment to ensuring that stories that are 'gifted' to the project do not simply remain in the realm of the academy, but are reinserted into the public domain to promote dialogue. In this regard, the embracing of a performative social science (Gergen \& Gergen, 2010) is a cornerstone of the project, with much of the academic analyses being translated and complemented by other modalities of representation, such as poetry, drama, photography, and a publicly accessible archive (see http://www.apartheidarchive.org) containing all the stories and products of the project (Sonn et al., 2013).

For reasons discussed in this article, including the constitutive license of recalling, memory, and the interpretative biases inherent in qualitative work, it is important to emphasise that the stories and narratives that are being collected cannot constitute a reflection of 'what really happened' during the apartheid period, nor can it provide a picture of the reality of apartheid or post-apartheid South Africa. Nonetheless, we believe that this project and the stories and narratives that it is currently generating will serve the important function of not allowing one of the most horrendous systems of institutionalised racism to be elided, suppressed, and denied. Importantly too, this project offers those who participate in it an opportunity, through their submission of their personal stories, to work through aspects of their lives during the apartheid period, so as to take greater control of their past and present. Indeed, as Krog (in Villa-Vicencio, 2004) observes, allowing people the opportunity to tell their personal stories of past trauma allows them to take control not simply of their past, but also of their futures:

The function of the archive is not simply to memorialise, it is also to mourn; and to mourn is to transcend that which is lost. (Derrida, in Villa-Vicencio, 2004, Oublie, mémoire et vigilance)

\section{Funding}

The authors gratefully acknowledge the research funding received from the University of the Witwatersrand for the Apartheid Archive Project.

\section{Notes}

1. Rüsen (in Villa-Vicencio, 2004) comments on similar processes of denial among large sections of the German public during the period immediately following the Holocaust.

2. To deny our past transgressions, we believe, is to deny the humanity of those against whom we have transgressed, and to diminish the humanity of the other is to make future transgressions against the latter all the easier.

\section{References}

Addison, R. B. (1992). Grounded hermeneutic research. In B. F. Crabtree \& W. L. Miller (Eds.), Doing qualitative research (pp. 145-162). Newbury Park, CA: SAGE.

Bond, P. (2000). Elite transition. London, England: Pluto Press. 
Cassan, B., Cayla, O., \& Salazar, P. (2004). Dire la vérité, faire la réconciliation, manquer la réparation [Speaking the truth, reconciling and failing to offer reparation]. In B. Cassan, O. Cayla, \& P. Salazar (Eds.), Vérité, réconciliation, reparation [Truth, reconciliation and reparation] (pp. 13-26). Paris, France: Seuil.

Chase, S. E. (1995). Taking narrative seriously: Consequences for method and theory in interview studies. In R. Josselson \& A. Lieblich (Eds.), Interpreting experience: The narrative study of lives. Thousand Oaks, CA: SAGE.

City Press. (2014, February 20). Another UFS 'racist' attack makes headlines. City Press. Retrieved from $\mathrm{http}: / / w w w . c i t y p r e s s . c o . z a / n e w s /$ another-ufs-racist-attack-makes-headlines/

Desai, A. (2002). 'We are the poors': Community struggles in post-apartheid South Africa. New York, NY: Monthly Review Press.

Duncan, N., Stevens, G., \& Sonn, C. (2012). Of narratives and nostalgia. Peace and Conflict: Journal of Peace Psychology, 18, 205-213.

Eagle, G., \& Bowman, B. (2013). Self-consciousness and impression management in the authoring of apartheid related narratives. In G. Stevens, N. Duncan, \& D. Hook (Eds.), Race, memory and the Apartheid Archive: Towards a transformative psychosocial praxis (pp. 275-294). London, England: Palgrave Macmillan.

Essed, P. (1991). Understanding everyday racism. Newbury Park, CA: SAGE.

Faul, M. (2008, February 29). Apartheid dead, but racism endures. Retrieved from http://www.huffingtonpost.com/huff-wires/20080229/south-africa-racism-endures/

Foucault, M. (1975). Tales of murder. In M. Foucault (Ed.), I, Pierre Rivière, having slaughtered my mother, my sister, and my brother ... (pp. 199-211). Lincoln, NE: University of Nebraska Press.

Gergen, M. M., \& Gergen, K. J. (2010). Performative social science and psychology. Forum: Qualitative Social Research, 12(1). Retrieved from http://www.qualitative-research.net/index.php/fqs/ article/ view/1595

Gqubule, D. (Ed.). (2006). Making mistakes, righting wrongs: Insights into Black Economic Empowerment. Johannesburg, South Africa: Jonathan Ball.

Hatch, M. J., \& Cunliffe, A. L. (2006). Organisation theory: Modern, symbolic, and postmodern perspectives. New York, NY: Oxford University Press.

Hook, D. (2013). On animal mediators and psychoanalytic reading practice. In G. Stevens, N. Duncan, \& D. Hook (Eds.), Race, memory and the Apartheid Archive: Towards a transformative psychosocial praxis (pp. 146-162). London, England: Palgrave Macmillan.

hooks, b. (1990). Marginality as a site of resistance. In R. Ferguson, M. Gever, T. Min-Ha, \& C. West (Eds.), Out there: Marginalization and contemporary cultures (pp. 341-343). Cambridge: The MIT Press.

Hyden, M., \& Overlien, C. (2004). 'Doing' narrative analysis. In D. K. Padgett (Ed.), The qualitative research experience (pp. 250-268). New York, NY: Thomson Brooks/Cole.

Josselson, R., \& Lieblich, A. (Eds.). (1995). Interpreting experience: The narrative study of lives. Thousand Oaks, CA: SAGE.

Laubscher, L. (2013). Working with the Apartheid Archive: Or, of witness, testimony, and ghosts. In G. Stevens, N. Duncan, \& D. Hook (Eds.), Race, memory and the Apartheid Archive: Towards a transformative psychosocial praxis (pp. 45-60). London, England: Palgrave Macmillan.

Lieblich, A., Tuval-Mashiach, R., \& Zilber, T. (1998). Narrative research: Reading, analysis, and interpretation (Applied Social Research Methods Series, 47). Thousand Oaks, CA: SAGE.

Long, C. (2013). Transitioning racialised spaces. In G. Stevens, N. Duncan, \& D. Hook (Eds.), Race, memory and the Apartheid Archive: Towards a transformative psychosocial praxis (pp. 61-80). London, England: Palgrave Macmillan.

Macleod, C. (2004). Writing into action: The critical research endeavour. In D. Hook, N. Mkhize, \& P. Kiguwa (Eds.), Critical psychology (pp. 523-539). Lansdowne, South Africa: UCT Press.

Mail \& Guardian. (2014, February 26). NWU Sieg Heil was not innocent, says education department. Mail \& Guardian. Retrieved from http://mg.co.za/article/2014-02-26-nwu-sieg-heil-was-not-innocent-sayseducation-dept

Marx, K. (1869/1977). The eighteenth Brumaire of Louis Bonaparte. In K. Marx \& F. Engels (Eds.), Selected works (Vol. 1, pp. 398-487). Moscow, Russia: Progress Publishers. 
Nuttall, S. (2009). Entanglement: Literary and cultural reflections on post-apartheid. Johannesburg, South Africa: Wits University Press.

Ratele, K., \& Shefer, T. (2013). Desire, fear and entitlement: Sexualising race and racialising sexuality in (re) membering apartheid. In G. Stevens, N. Duncan, \& D. Hook (Eds.), Race, memory and the Apartheid Archive: Towards a transformative psychosocial praxis (pp. 188-207). London, England: Palgrave Macmillan.

Reuters. (2008, May 31). South Africa violence toll rises to 62. Reuters. Retrieved from http://www.reuters. com/article/2008/05/31/us-safrica-violence-deaths-idUSL31541720080531

Ross, T. (2000). The Richmond narratives. In R. Delgado \& J. Stefancic (Eds.), Critical race theory (2nd ed., pp. 42-51). Philadelphia, PA: Temple University Press.

Sands, R. G. (2004). Narrative analysis: A feminist approach. In D. K. Padgett (Ed.), The qualitative research experience (pp. 48-75). New York, NY: Thomson Brooks/Cole.

Shefer, T. (2013). Intersections of 'race', sex and gender in narratives on Apartheid. In G. Stevens, N. Duncan, \& D. Hook (Eds.), Race, memory and the Apartheid Archive: Towards a transformative psychosocial praxis (pp. 169-187). London, England: Palgrave Macmillan.

Sonn, C. C. (2013). Engaging with the Apartheid Archive Project: Voices from the South African diaspora in Australia. In G. Stevens, N. Duncan, \& D. Hook (Eds.), Race, memory and the Apartheid Archive: Towards a transformative psychosocial praxis (pp. 128-145). London, England: Palgrave Macmillan.

Sonn, C. C., Stevens, G., \& Duncan, N. (2013). Decolonisation, critical methodologies, and why stories matter. In G. Stevens, N. Duncan, \& D. Hook (Eds.), Race, memory and the Apartheid Archive: Towards a transformative psychosocial praxis (pp. 295-314). London, England: Palgrave Macmillan.

South African History Online. (2014). Apartheid Legislation 1850s-1970s. Retrieved from http://www.sahistory.org.za/politics-and-society/apartheid-legislation-1850s-1970s\#content-top

Statistics South Africa. (2011). Labour Force Survey. Quarter, 3, 2011.

Stevens, G., Duncan, N., \& Hook, D. (2013). The Apartheid Archive Project, the psychosocial and political Praxis. In G. Stevens, N. Duncan, \& D. Hook (Eds.), Race, memory and the Apartheid Archive: Towards a transformative psychosocial praxis (pp. 1-17). London, England: Palgrave Macmillan.

Stevens, G., Duncan, N., \& Sonn, C. C. (2013). Memory, narrative and voice as liberatory praxis in the Apartheid Archive. In G. Stevens, N. Duncan, \& D. Hook (Eds.), Race, memory and the Apartheid Archive: Towards a transformative psychosocial praxis (pp. 25-44). London, England: Palgrave Macmillan.

Straker, G. (2013). Unsettling whiteness. In G. Stevens, N. Duncan, \& D. Hook (Eds.), Race, memory and the Apartheid Archive: Towards a transformative psychosocial praxis (pp. 91-108). London, England: Palgrave Macmillan.

Sullivan, L. G., \& Stevens, G. (2013). Gendered subjectivities and relational references in black women's narratives of apartheid racism. In G. Stevens, N. Duncan, \& D. Hook (Eds.), Race, memory and the Apartheid Archive: Towards a transformative psychosocial praxis (pp. 208-227). London, England: Palgrave Macmillan.

Terre Blanche, M. (2006). Two nations: Race and poverty in post-apartheid South Africa. In G. Stevens, V. Franchi, \& T. Swart (Eds.), A 'race' against time (pp. 73-90). Pretoria, South Africa: UNISA Press.

Thakali, T. (2008, March 8). Eight weeks of racism. The Star, p. 15.

Villa-Vicencio, C. (2004). Oublie, mémoire et vigilance [Failure to remember, memory and vigilance]. In B. Cassan, O. Cayla, \& P. Salazar (Eds.), Vérité, réconciliation, reparation [Truth, reconciliation and reparation] (pp. 319-338). Paris, France: Seuil.

Villa-Vicencio, C. (2008, March 14-19). A neglected moral vision. Mail \& Guardian, p. 24. 